\title{
Propranolol in the Treatment of Infantile Hemangiomas
}

\section{Xin Tan \\ Shu Guo (D) \\ Chenchao Wang}

Department of Plastic Surgery, First Hospital of China Medical University, Shenyang, Liaoning Province, People's Republic of China
Correspondence: Chenchao Wang Department of Plastic Surgery, First Hospital of China Medical University, 155 North Nanjing Street, Shenyang, I I000 I, Liaoning Province, People's Republic of China

Tel +86-|384200036|

Fax +86-24-83282592

Email ccwang@cmu.edu.cn

\begin{abstract}
Propranolol, as the first generation of $\beta$-blocker family, was initially introduced in the clinical application for tachycardia and hypertension in the 1960s. However, the occasional discovery of propranolol in the involution of infantile hemangiomas (IHs) brought us a new perspective. IHs are the most common infantile tumor, affecting $4-10 \%$ newborns. So far, oral propranolol is the first-line medication for IHs treatment. At the same time, local injection and topical propranolol are developing. Despite the worldwide application, the precise mechanism of propranolol of IHs has not been completely studied. In this article, we reviewed and summarized the current information on pharmacology, mechanism, efficacy, and adverse effects of propranolol. Novel design of biomaterials and bioactive molecules are needed for new treatment and ideal pathway to attain the minimal effective treatment concentration and eliminate the adverse effects.
\end{abstract}

Keywords: infantile hemangiomas, propranolol, treatment

\section{Introduction}

Propranolol was used for treatment firstly in the 1960s. ${ }^{1}$ After the serendipitous finding that propranolol accelerated the healing of IHs by the French team, ${ }^{2,3}$ more researches proved the efficacy and propranolol is now recognized as the first-line medication for IHs. ${ }^{4}$ In the beginning, oral propranolol starts from $1 \mathrm{mg} / \mathrm{kg} /$ day to 2-3 mg/kg/day for at least 6-12 months. ${ }^{4}$ For further examination, $1.5-2.0 \mathrm{mg} / \mathrm{kg}$ / day is considered as the optimal dosage. ${ }^{5}$ IHs occur in about $4-10 \%$ infants, causing them the most common infantile neoplasms. ${ }^{6-9}$ The pathology of IHs is the hyperplasia of the endothelial cells. Distinguished from other vascular anomalies, IHs are expressing glucose transporter-1 protein (GLUT-1). ${ }^{6,7,10,11}$ There are two phases in the progression of IHs, proliferative phase and involution phase. Due to the involution, most of the IHs need no intervention and only $10 \%$ of the patients require medication. ${ }^{12}$ Though propranolol is the proper choice for IHs, the adverse events, for example bradycardia and hypoglycemia are noticeable. Other than the medication, surgery and laser management are of great importance. However, along with the emergence of the propranolol therapy, those interventions are rarely used. ${ }^{11}$ Generally speaking, surgery should not be recommended in the infant period because of the high anesthetic risks. ${ }^{13-15}$ In the following situations, surgery intervention could be considered. The first is that the local treatment and medication are not working. The second is that the advance surgery will be beneficial for the further reconstruction, concerning the ears or the eyelids. The third is that the lesions are limited in easily resectable areas. The last is that the surgery must be 
done and there are of no differences in the surgery timing. ${ }^{13-15}$ Pulsed-dye laser (PDL) has been applied for IHs in decades. It is widely accepted that PDL is safe and effective in IHs. The related side effects include skin atrophy, bleeding, scar, and pigment variations. ${ }^{16}$ Since the advent of propranolol treatment, the practice is less common. Some researchers reported that PDL possessed a higher incidence of side events in the infant period. ${ }^{15,17}$ PDL can only eliminate the superficial lesions and the deep tissues are not affects, which leads to the residual changes. ${ }^{18,19}$ The combination of Nd:YAG laser and PDL could solve the issue mentioned before. ${ }^{20} \mathrm{Nd}$ :YAG laser is able to penetrate $5-6 \mathrm{~mm}$ deep in the tissue. Hence, the combination is effective and bring a new perspective in the laser therapy. In this review, we focus on the role of propranolol in IHs. Over the decades of clinical practice, the specific mechanism of propranolol action has not been fully investigated. We aim to review and update the current information on pharmacology, mechanism, efficacy, and adverse effect of propranolol.

\section{Pharmacology of Propranolol}

Propranolol is a non-selective $\beta$-adrenergic receptor blocker. Its chemical formula is 1-Isopropylamino3-1-naphthyloxy-2-propanol $\left(\mathrm{C}_{16} \mathrm{H}_{21} \mathrm{NO}_{2}\right){ }^{21}$ It is processed into the hydrochloride salt for application. As a cardiovascular $\beta$-adrenergic receptor blocker, propranolol is recommended for hypertension, tachycardia, angina pectoris, and so on. It is also used to inhibit cardiac remodeling. In the hyperthyroidism, anxiety, and tremor, propranolol plays an important role in controlling the sympathetic overreaction. There are some other indications like the prophylaxis of migraine, too. ${ }^{22}$

Propranolol's chemical structure is similar to catecholamine, so they can compete with the $\beta$-adrenergic receptors. Catecholamine works through the forming of a hydrogen bond between the hydroxyl group and the receptors. ${ }^{1}$ However, propranolol is lack of hydroxyl group, unable to activate the receptors and hold the relative $\beta$-adrenergic activity. Propranolol also possess a membrane stabilizing quality by blocking the sodium and calcium channels. ${ }^{1}$ But the phenomenon only happens in the extremely high dose, and has no clinical meanings.

The therapeutic effect of propranolol for IHs is via the regulation of renin-angiotensin system (RAS). ${ }^{23-28} \mathrm{IHs}$ ' endothelium shows an expression of components of RAS $^{25}$ and pro-renin receptor. ${ }^{26}$ Researchers has found that angiotensin II(ATII) promotes the capillary proliferation of IHs and in vitro generates a blast-like biological structure likely to the lining endothelial cells in IHs. ${ }^{25}$ The other opinion about the propranolol mechanism is angiogenesis suppression. Upregulation of angiogenesis transcription factors like hypoxia-inducible factor (HIF-1 $\alpha$ ) and vascular endothelial growth factor-A (VEGF-A) is common in neonates with $\mathrm{IHs}^{29}$ and when treated with propranolol we can observe a remarkable dose-dependent reduction in HIF- $1 \alpha$ and the VEGF-A. ${ }^{30-32}$ Overall, propranolol plays a positive role on IHs.

Pharmacokinetically, all of the oral propranolol is nearly absorbed from the intestine. But the blood concentrations are variable. After oral intake, propranolol can be detected within $30 \mathrm{~min}$ and reaches peak at about $60 \mathrm{~min}$. The common tablet form is propranolol hydrochloride which release slowly and peak plasma concentrations are attained after about $6 \mathrm{~h}$. The liquid form of propranolol should be taken right after meals. And the pharmacokinetic analysis shows that the highest blood concentration is observed at 3 hours after administration. ${ }^{33}$ There is first pass elimination effect of liver, so after oral administration the effective circulation propranolol to the lesion area is depending. ${ }^{34}$ Propranolol is extensively distributed in many organs and can pass through the blood brain barrier. Over $90 \%$ of the plasma propranolol is bound to the blood protein. Propranolol follows the first order elimination rule, independent of blood concentration and intake dosage. Propranolol is excreted from the body via kidney, so the half-life correlates the renal function. ${ }^{34}$

\section{Biological Effects of Propranolol}

Propranolol has been applied in the treatment of IHs for more than ten years. It is widely acknowledged that the influence of propranolol on IHs relies on the RAS modulation. ${ }^{28} 6$ months therapy is considered as a better duration. ${ }^{35}$ In thousands of articles, the biological efficacy of propranolol to IHs is verified.

As a crucial transcription factor in angiogenesis, HIF$1 \alpha$ takes a crucial part in IHs. More and more IHs infants are reported suffering from perinatal hypoxia. We could deduce that the increase of HIF- $1 \alpha$ results from the hypoxic events, like prematurity and pre-eclampsia. ${ }^{36,37}$ ATII is involved in the procedure of HIF-1 $\alpha$ upregulation. Thus, the inhibiting ability of propranolol to ATII may exert huge effects on prohibiting angiogenesis via downregulating the pro-angiogenesis pathway by HIF- $1 \alpha .{ }^{37}$

Propranolol may also function via enhancing capillary endothelium apoptosis. ${ }^{38,39}$ Through the $\beta$-adrenergic 
blockade, propranolol decreases the tumor blood flow by enhancing vasoconstriction and inhibiting vasodilation. ${ }^{38}$

Oral propranolol is made up of two different isomers, S-propranolol and R-propranolol. ${ }^{23,40}$ S-propranolol possess the active $\beta$-adrenergic blocking capacity, while $\mathrm{R}$-propranolol is an inactive isomer. Some scholars believe it is the R-propranolol participates in the therapeutic course of IHs. ${ }^{23,40}$ Compared with the control groups, angiopoietinlike 4 is significantly lower expressed in the R-propranolol treatment group both in vitro and in the murine models. Therefore, R-propranolol intervene the IHs via downregulating angiogenesis factors and then inhibit angiogenesis. ${ }^{23}$ R-propranolol eliminates the hemangiomas and activates some tumor suppression genes as betaine homocysteine methyltransferase and early growth response- 1 genes. ${ }^{23}$ The above brings us a new perspective of innovating the clinical treatment to use the R-propranolol alone to realize tumor decrement while avoiding side effects.

As we all know, there are two enantiomers of propranolol, R-propranolol and S-propranolol. Propranolol is mainly used in cardiovascular and neural system. Nevertheless, the efficacy of propranolol is not proportional to the receptors level. ${ }^{41,42}$ In the further studies, researchers unveil the role of R-propranolol and S-propranolol. The researchers proposed that R-propranolol showed an influence on the SOX18 transcriptional factor and then played an important role in the anti-angiogenic process. ${ }^{40}$ SOX18 is widely studied and function in the neo-vascularization. ${ }^{43,44}$ This theory also supports our ideas the it is the R-propranolol that functions as the crucial mediator in IHs.

Even though the large randomized controlled trial (RCT) is the gold standard for the effectiveness comparison between propranolol and steroids, it is not practicable or ethical. We use other methods to evaluate. In a retrospective cohort analysis, ${ }^{45}$ the researchers compared 68 neonates treated with propranolol at $2 \mathrm{mg} / \mathrm{kg} / \mathrm{day}$, with 42 infants treated with oral steroids at $4 \mathrm{mg} / \mathrm{kg} / \mathrm{day}$. The analysis of the results is rectified with matching ages, lesion area, sites and lesion type. The neonates treated with propranolol shows greater lesion clearance that those undergoing steroids therapy. In the cases infants need secondary surgery, propranolol is also a better choice compared to steroids $(12 \%$ vs $29 \%, P<0.01){ }^{45}$

\section{Use of Propranolol in IHs}

After the serendipitous finding, the old drug, propranolol has its new application for $\mathrm{IHs}^{3}$ Nowadays, oral propranolol is proven to be the first-line medication in IHs. ${ }^{46-48}$ The exploration of local administration pathway as local injection and topical application is in progress. ${ }^{49}$ IHs are the most usual infantile soft tissue benign neoplasms. IHs are the abnormal vascular hyperplasia and can exist nearly everywhere over the body. IHs are generally diagnosed from one week to one month, may present a rapid progress in one or three months. Approximately, $90 \%$ of IHs slowly involute into fibrous and adipose tissue. Most of the tumors are able to resolve and need no intervention, while the problematic ones should be treated. Those include IHs that could lead to large scar, disfiguration and dysfunction, airway or hepatic IHs, ulceration, and related latent abnormalities. ${ }^{50,51}$

Diagnosis of most IHs is carried out though the medical records and physical examinations. The initial medical history should contain the birth history, the timing of IHs discovery, the duration of IHs growing, the timing of cessation of IHs development, and the complications. ${ }^{11,16,52-56}$ After the first diagnosis, the patients should come for a follow-up visit to assess the diseases at 1-3 months. The doctors must evaluate the general status and the detailed information about the IHs including site, size, color, amount and the indications of involution. ${ }^{57,58}$ At the same time, imaging materials must be collected sequentially from each subsequent visit to the 6 months after intervention. ${ }^{8,59}$ The treatment outcomes should be estimated by visual analog scale (VAS) and are divided into four levels, excellent, good, poor and no response. ${ }^{60}$

IHs should be distinguished from other vascular tumors, involving benign neoplasms like congenital hemangiomas (CHs), borderline neoplasms like Kaposiform hemangioendothelioma, and malignant neoplasms like epithelioid hemangioendothelioma. IHs must be identified from vascular malformations, too ${ }^{7,61-63}$ (Table 1). CHs are completely mature at birth. They do not have two different phases like IHs. ${ }^{6,61-63} \mathrm{CHs}$ show a pattern like bluish-red mass with dilated capillaries on the surface or grey neoplasms with a pale halo. Vascular malformations are born abnormal vascular tissues. They are stable after labor and do not have accurate proliferating or involution phase. They just develop with body growth. The pathogenic stimuli including infection, hormone variation, injury and so on can expand the malformations. $^{7,10,54}$

The administration dose is recommended starting from $1 \mathrm{mg} / \mathrm{kg} /$ day to cardiovascular proper $2-3 \mathrm{mg} / \mathrm{kg} /$ day in many published clinical guidelines ${ }^{8,11,57,64}$ (Table 2). Based on existent articles, the target dosage is using the empirical maximal dosage of $2-3 \mathrm{mg} / \mathrm{kg} /$ day to treat IHs. ${ }^{65}$ 
Table I Difference Between Vascular Malformation and Infantile Hemangiomas

\begin{tabular}{|c|c|c|}
\hline Features & $\begin{array}{l}\text { Infantile } \\
\text { Hemangiomas }\end{array}$ & Vascular Malformation \\
\hline $\begin{array}{l}\text { Age of } \\
\text { emergence }\end{array}$ & Often after birth & At birth \\
\hline Proliferation & $\begin{array}{l}\text { With a rapid } \\
\text { proliferation phase }\end{array}$ & $\begin{array}{l}\text { Growth with the body } \\
\text { development }\end{array}$ \\
\hline Involution & Yes & No \\
\hline Epidemiology & $\begin{array}{l}\text { Female domination } \\
(3: 1)\end{array}$ & No prevalence \\
\hline $\begin{array}{l}\text { Risk factors } \\
\text { of expansion }\end{array}$ & None & $\begin{array}{l}\text { Hormone changes, trauma, } \\
\text { infections and so on }\end{array}$ \\
\hline $\begin{array}{l}\text { Physical } \\
\text { examination }\end{array}$ & $\begin{array}{l}\text { Palpation of a solid } \\
\text { mass }\end{array}$ & $\begin{array}{l}\text { Palpation of thrill or } \\
\text { pulsation, auscultation of } \\
\text { vascular murmur }\end{array}$ \\
\hline Diagnosis & $\begin{array}{l}\text { Based on medical } \\
\text { history and clinical } \\
\text { manifestation }\end{array}$ & $\begin{array}{l}\text { Based on medical history, } \\
\text { clinical manifestation and } \\
\text { imaging examination }\end{array}$ \\
\hline Treatment & $\begin{array}{l}\text { Most of the IHs can } \\
\text { involute before } 4 \text { years } \\
\text { old. The high risk ones } \\
\text { need oral propranolol } \\
\text { intervention, laser or } \\
\text { surgery. }\end{array}$ & $\begin{array}{l}\text { The symptomatic ones } \\
\text { need treatment such as } \\
\text { sclerotherapy, surgery or } \\
\text { laser. }\end{array}$ \\
\hline
\end{tabular}

Notes: Data from references., ${ }^{7,61-63}$

Abbreviation: $\mathrm{IHs}$, infantile hemangiomas.

To date, there is lacking of large-scale RCTs to confirm the minimal dosage to attain the rapid involution of IHs. The American guidelines ${ }^{11}$ recommend treatment at $2-3 \mathrm{mg} /$ $\mathrm{kg}$ /day. The Spanish consensus guidelines ${ }^{66}$ recommend treatment at $3 \mathrm{mg} / \mathrm{kg} /$ day, however the Australasian guidelines give a maximal dosage of $1-2 \mathrm{mg} / \mathrm{kg} / \mathrm{day}$, unless a lower dosage is clinically effective. ${ }^{57}$

The ideal timing of starting intervention is not reported in most known guidelines, and there are no related trials emphasized on the optimal starting time point and duration of treatment. Conventionally, medication ought to be started as soon as possible, in the early phase of IHs development, before the irreversible damage is initiated. ${ }^{57}$ The duration of propranolol usage is recommended for at least six months, usually lasting 12 months or longer. ${ }^{6-68}$ Some researchers recommend the treatment is continued till the involution of IHs, and an average of 14 months is suggested. ${ }^{69}$

After reviewing all the materials, we recommend the target propranolol dosage is 2 to $3 \mathrm{mg} / \mathrm{kg} / \mathrm{d}$ and the medication should start from $0.7-1.0$ to $2.0-2.5 \mathrm{mg} / \mathrm{kg} / \mathrm{d}$ in three divided doses at an interval of at least 3 days. Propranolol has a maximal influence on heart rate and blood pressure in three hours after application ${ }^{70}$ and the drug reaction often happens in the initial medication. ${ }^{71}$ Therefore, most specialists recommend the blood pressure and heart rate ought to be monitored in the first and second hour after the initial administration and each increment. If there is no obvious variation for these periods, patients are supposed to be stable during the propranolol intervention. ${ }^{8,70}$ However, the Australian guidelines suggest those infants without risk factors could start the medication at home and the monitoring process is only for those at the risk of hypoglycemia and related medical issues. ${ }^{57}$ In the whole treatment procedure, regular subsequent monitoring is of necessity. ${ }^{8,57}$ The ulceration in IHs is regarded as a risk factor. Ulceration can cause bleeding, pain, infection and secondary lesions. ${ }^{72,73}$ The ulcerated type needs intervention as soon as possible and the oral propranolol is still the first choice at the dose of $2-3 \mathrm{mg} /$ $\mathrm{kg} / \mathrm{d}$. In the course of ulcerated IHs, bleeding should be taken into consideration. Though bleeding is the major concern, the bleeding degree of ulcerated IHs is minor and can be easily handled with compression. ${ }^{72,73}$

Though oral propranolol is well endurable, the medication is still facing several adverse events, ${ }^{69}$ which leads to more studies about local intervention like topical propranolol. ${ }^{74}$ But in most researches, oral propranolol is the best option. ${ }^{74}$ In a clinical trial, which is about the comparison between oral propranolol at $3 \mathrm{mg} / \mathrm{kg} / \mathrm{d}$ and $1 \%$ topical propranolol three times a day, the results show a faster curative effect in the oral propranolol group. In conclusion, topical propranolol therapy is less effective and should be considered only when the patients suffer from extreme side effects.

In a large meta-analysis of 41 studies, propranolol responding rate reaches $82-100 \%{ }^{75}$ Hermans et al ${ }^{76}$ find the treatment effect starts within 3 days, and after 2.0$2.5 \mathrm{mg} / \mathrm{kg} /$ day for $12-18$ months' oral propranolol treatment there is obvious improvement in $99 \%$ of patients. In two placebo controlled RCTs, ${ }^{35,77}$ anticipated treating outcomes are observed in five weeks therapy, with persistent amelioration in lesions over the process, contrast to the controlled placebo groups. In a prospective cohort study, $50 \%$ of all 188 neonates treated with $2 \mathrm{mg} / \mathrm{kg}$ /day oral propranolol for a median length of 8 months gets a perfect response, over $70 \%$ lesion deduction. Only $20 \%$ infants received a less satisfactory outcome, less than $30 \%$ 
Table 2 Current Clinical Guideline for Infantile Hemangiomas

\begin{tabular}{|c|c|c|c|}
\hline & Indications & Administration of Oral Propranolol & $\begin{array}{l}\text { Course of } \\
\text { Treatment }\end{array}$ \\
\hline $\begin{array}{l}\text { America } \\
(2019)\end{array}$ & $\begin{array}{l}\text { IHs that could lead permanent scar, disfiguring, } \\
\text { dysfunction and ulceration, hepatic and airway IHs. }\end{array}$ & A dose of 2 to $3 \mathrm{mg} / \mathrm{kg} / \mathrm{d}$ & $\begin{array}{l}6 \text { months to } 12 \\
\text { months (occasionally } \\
\text { longer) }\end{array}$ \\
\hline $\begin{array}{l}\text { Europe } \\
(2015)\end{array}$ & $\begin{array}{l}\text { Obstructive hemangiomas, ulcerated hemangiomas } \\
\text { and large facial hemangiomas }\end{array}$ & Start from I mg/kg/d until 2 or $3 \mathrm{mg} / \mathrm{kg} / \mathrm{d}$ & 6 months standard \\
\hline $\begin{array}{l}\text { Australia } \\
(2017)\end{array}$ & $\begin{array}{l}\text { Life or function-threatening IHs (Airway } \\
\text { hemangioma, visual impairment, spinal cord } \\
\text { involvement, high flow hemangioma with cardiac } \\
\text { compromise, hemangiomas causing hypothyroidism, } \\
\text { large hemangiomas interfering with physical } \\
\text { development, systemic hemangiomas), ulcerated } \\
\text { hemangiomas or IHs at significant risk of ulceration } \\
\text { (Lip and Perineum) and hemangiomas with significant } \\
\text { risk of deformity and/or psychosocial impact }\end{array}$ & $\begin{array}{l}\text { Start at a dosage of } 1 \mathrm{mg} / \mathrm{kg} / \mathrm{d} \text {, divide the dose into } \\
\text { twice a day and gradually increase to } 2 \mathrm{mg} / \mathrm{kg} / \mathrm{d} \\
\text { Divided doses twice daily, unless a lower dosage is } \\
\text { clinically effective }\end{array}$ & $\begin{array}{l}\text { A variation from } 3 \text { to } \\
24 \text { months. }\end{array}$ \\
\hline $\begin{array}{l}\text { Japan } \\
(2020)\end{array}$ & $\begin{array}{l}\text { Alarming hemangioma/life-threatening hemangioma } \\
\text { in the proliferating phase and in patients with } \\
\text { cosmetic problems, such as giant lesions in the face, } \\
\text { those with ulcerated and hemorrhagic lesions, and } \\
\text { those who may develop functional impairments. }\end{array}$ & $\begin{array}{l}\text { Start from } 0.7-1.0 \text { to } 2.0-2.5 \mathrm{mg} / \mathrm{kg} / \mathrm{d} \text { in three } \\
\text { divided doses at an interval of at least } 3 \text { days }\end{array}$ & $\begin{array}{l}\text { The mean duration is } \\
9.1 \text { months and } \\
\text { basically up to } 12 \\
\text { months. }\end{array}$ \\
\hline
\end{tabular}

Notes: Data from reference $8,11,57,64$.

Abbreviations: IHs, infantile hemangiomas; $\mathrm{mg} / \mathrm{kg} / \mathrm{d}$, (drug) milligram per (bodyweight) kilogram per day.

reduction in the lesion size. In this research, a crucial relationship between early treatment and increased treatment efficacy, with $45 \%$ having bad responses when the intervention started in 18-27 months of age, and just 7\% having bad response when the treatment is between $0-2$ months of age. ${ }^{78}$

The phenomenon of rebound growth is observed in up to $25 \%$ in the IHs patients with propranolol treatment. ${ }^{75,78-80}$ In a cohort study, female neonates, advanced interruption of medication (prior to 9 months of age) and deep IHs are considered as possible pathogenic factors. The researchers discover a profound discrepancy of rebound growth risk of the infants where the termination of treatment is before 9 months of age compared to after 24 months of age. In further analysis of this research, females and deep IHs are increasing the rebounding risk to the other factors like the size and location of lesions. ${ }^{79}$

Most of the researches depend on the clinical doctors to measure the morphology of the lesions and subjectively evaluate the degree of amelioration. Moreover, some studies describe the ameliorations with broad categories, excellent, moderate, or poor response. These boundaries are lack of specific standards to differentiate, only by the percentage of lesion reduction after intervention. Due to the deficiency of the standardized measurement, the results of the studies are still subjective and not convincing. The above emphasizes the importance to apply a standardized rule to evaluate the clinical manifestation of $\mathrm{IHs}^{81}$

\section{Adverse Effects}

Propranolol has been considered safe with fewer adverse effects compared to the general administration of steroids. $^{45,82}$ In a retrospective cohort study about the comparison between propranolol and steroids in IHs infants, the steroids group present a $100 \%$ adverse issues, compared to $1 \%$ in the propranolol group. The adverse event in the propranolol group is hypoglycemia, a rather rare complication with few reports. Other common complications include sleeping disorders, ${ }^{83}$ agitation and gastrointestinal disorders are not stated in this article. ${ }^{84}$ To date, there is no large-scale RCT studying on the adverse effects of propranolol treatments.

There are various complications rates reported from $7 \%$ to $96 \%,{ }^{56,58,76}$ however, only about $3 \%$ of IHs neonates suffer from severe adverse complications and in need of propranolol termination. ${ }^{58}$ Phillips et al found the 
adverse effect rate of oral propranolol on IHs infants is $27 \%$. And the most usual complication is sleep disorder (14\%). Four percent of the study kids necessitate propranolol cessation. ${ }^{78}$ There are many possible reasons leading to the adverse effects rate. Nevertheless, sleep disorder, hypotension, bradycardia and hypoglycemia are of consistence in various articles. ${ }^{85}$ Only a few other complications are diversely reported. Patient demographics and individual differences are possible pathogenic factors.

In a multicenter placebo controlled $\mathrm{RCT}^{35}{ }^{35}$ they design three studying groups, propranolol $1 \mathrm{mg} / \mathrm{kg} / \mathrm{day}$, propranolol $3 \mathrm{mg} / \mathrm{kg} /$ day and a placebo group in a six months course of treatment. The rate of adverse effects is $90 \%, 96 \%$ and $76 \%$ respectively. The reasons why the placebo group reveals a relatively high are not discussed. The common adverse events are agitation, sleep disturbance, gastrointestinal disturbance including vomiting, diarrhea, constipation, cool peripheries, and bronchitis which are similar to other articles. The other serious outcomes like bradycardia, hypotension, and hypoglycemia are rare. While in another study, the researchers use a low propranolol dose of $1.5-2.0 \mathrm{mg} / \mathrm{kg} /$ day. ${ }^{86}$ They find a rather good outcome with $7 \%$ of adverse event rate and there is no need to stop the medication.

To sum up, the common adverse events of oral propranolol for IHs are sleeping disorder and agitation, which may lead to the interruption of treatment. ${ }^{87,88}$ Other known adverse events incorporate bradycardia, hypotension, bronchial disturbance and hypoglycemia. Mild side effects are digestive disorder (emesis, diarrhea or astriction) and anorexia. $^{89}$

Although short-term side effects of oral propranolol are widely studied, there is no systemic study on the underlying impact on the cognitive function. The propranolol is lipophilic and is easily attached to the brain blood barrier (BBB), which enable propranolol to cause central nervous system (CNS) influence. ${ }^{90}$ To date, there is a lack of published articles to analyze the long-term CNS effects such as cognitive level, memory, sleep, emotions and so on. According to a small case control study of 82 children with IHs, they get no profound difference of motor function, communication, social ability and physical development between the propranolol group and the non-propranolol group at the age of four. ${ }^{91}$ But the above-mentioned study is limited by its small scale and the only results at the age of four. On the contrary, researches on the CNS function of adult treated with propranolol find the distinction on memory, emotion, sleep and mental status between propranolol group and the placebo group. ${ }^{92}$ The discrepancy of propranolol adverse effects between children and adults may attribute to neural plasticity of the infants.

Propranolol is the first-line medication for IHs with obvious adverse events. It is of great importance to develop a novel biomaterial, bioactive molecules or other ideal pathway to attain the minimal effective treatment concentration, navigate precise drug delivery and eliminate the adverse effects. The golden-standard of treatment guideline has not reached a consensus. This status is caused by the absence of large RCTs and there are only a few small studies, most of which are cohort studies and meta-analysis with no unified criteria to measure clinical issues. At present, clinical doctors and researchers should depend on the current knowledge, experience and published materials to guide treatment and research and do more scientific researches to provide better treatment for the IHs patients.

\section{Conclusion}

After the serendipitous application of propranolol on IHs infants, ${ }^{3}$ the doctors have changed their idea on IHs treatment. To date, propranolol is the first-line agent and provides remarkable effects to the IHs patients. Based on articles' review and our clinical experience, the recommendatory usage of propranolol to IHs should start from $0.7-1.0$ to $2.0-2.5 \mathrm{mg} / \mathrm{kg} / \mathrm{d}$ in three divided doses at an interval of at least 3 days. And the first medication should be performed in hospital to monitor the infants' general status after intervention. Oral propranolol is considered as a safe and effective treatment; however, the adverse effects cannot be ignored and the additional evidences and researches are needed for better clinical outcomes.

\section{Disclosure}

The authors report no conflicts of interest in this work.

\section{References}

1. Ogrodowczyk M, Dettlaff K, Jelinska A. Beta-blockers: current state of knowledge and perspectives. Mini Rev Med Chem. 2016;16 (1):40-54. doi:10.2174/1389557515666151016125948

2. Itinteang T, Chudakova DA, Dunne JC, Davis PF, Tan ST. Expression of cathepsins B, D, and G in infantile hemangioma. Front Surg. 2015;2:26. doi:10.3389/fsurg.2015.00026

3. Leaute-Labreze $\mathrm{C}$, de la Roque ED, Hubiche T, Boralevi F, Thambo JB, Taieb A. Propranolol for severe hemangiomas of infancy. $N$ Engl $J$ Med. 2008;358(24):2649-2651. doi:10.1056/ NEJMc0708819

4. Lopez-Gutierrez JC. Clinical and economic impact of surgery for treating infantile hemangiomas in the era of propranolol: overview of single-center experience from La Paz Hospital, Madrid. Eur J Pediatr. 2019;178(1):1-6. doi:10.1007/s00431-018-3290-z 
5. Koh SP, Leadbitter P, Smithers F, Tan ST. $\beta$-blocker therapy for infantile hemangioma. Expert Rev Clin Pharmacol. 2020;13 (8):899-915. doi:10.1080/17512433.2020.1788938

6. Wildgruber M, Sadick M, Muller-Wille R, Wohlgemuth WA. Vascular tumors in infants and adolescents. Insights Imaging. 2019;10(1):30. doi:10.1186/s13244-019-0718-6

7. Adams DM, Brandao LR, Peterman CM, et al. Vascular anomaly cases for the pediatric hematologist oncologists-an interdisciplinary review. Pediatr Blood Cancer. 2018;65(1):e26716. doi:10.1002/pbc.26716

8. Hoeger PH, Harper JI, Baselga E, et al. Treatment of infantile haemangiomas: recommendations of a European expert group. Eur J Pediatr. 2015;174(7):855-865. doi:10.1007/s00431-015-2570-0

9. Yuan W, Wang X. Propranolol participates in the treatment of infantile hemangioma by inhibiting HUVECs proliferation, migration, invasion, and tube formation. Biomed Res Int. 2021;2021:6636891. doi: $10.1155 / 2021 / 6636891$

10. Steiner JE, Drolet BA. Classification of vascular anomalies: an update. Semin Intervent Radiol. 2017;34(3):225-232. doi:10.1055/ s-0037-1604295

11. Krowchuk DP, Frieden IJ, Mancini AJ, et al. Clinical practice guideline for the management of infantile hemangiomas. Pediatrics. 2019;143(1):e20183475. doi:10.1542/peds.2018-3475

12. Jung HL. Update on infantile hemangioma. Clin Exp Pediatr. 2021. doi:10.3345/cep.2020.02061

13. Greene AK. Management of hemangiomas and other vascular tumors. Clin Plast Surg. 2011;38(1):45-63. doi:10.1016/j. cps.2010.08.001

14. Couto RA, Maclellan RA, Zurakowski D, Greene AK. Infantile hemangioma: clinical assessment of the involuting phase and implications for management. Plast Reconstr Surg. 2012;130(3):619-624. doi:10.1097/PRS.0b013e31825dc129

15. Mulliken JB, Fishman SJ, Burrows PE. Vascular anomalies. Curr Probl Surg. 2000;37(8):517-584. doi:10.1016/S0011-3840(00) 80013-1

16. Darrow DH, Greene AK, Mancini AJ, et al. Diagnosis and management of infantile hemangioma. Pediatrics. 2015;136(4):e1060 e1104. doi:10.1542/peds.2015-2485

17. Witman PM, Wagner AM, Scherer K, Waner M, Frieden IJ. Complications following pulsed dye laser treatment of superficial hemangiomas. Lasers Surg Med. 2006;38(2):116-123. doi:10.1002/ lsm.20294

18. Batta K, Goodyear HM, Moss C, Williams HC, Hiller L, Waters R. Randomised controlled study of early pulsed dye laser treatment of uncomplicated childhood haemangiomas: results of a 1-year analysis. Lancet. 2002;360(9332):521-527. doi:10.1016/S0140-6736(02) 09741-6

19. Kessels JP, Hamers ET, Ostertag JU. Superficial hemangioma: pulsed dye laser versus wait-and-see. Dermatol Surg. 2013;39(3 Pt 1):414-421. doi:10.1111/dsu.12081

20. Negosanti F, Silvestri M, Bennardo L, et al. Nd:YAG laser in association with pulsed dye laser for the treatment of PHACES syndrome. Dermatol Reports. 2021;13(1):8751. doi:10.4081/dr.2021.8751

21. Town WG. The Merck index 13.2 CD-ROM edition from CambridgeSoft. J Chem Inf Comput Sci. 2004;44(5):1883-1885. doi:10.1021/ci0400462

22. Helena S. Martindale: the complete drug reference Brayfield Alison (Ed) Martindale: the complete drug reference pound $4594,688 \mathrm{pp}$ pharmaceutical press 9780857111395 0857111396. Emerg Nurse. 2014;22(5):12. doi:10.7748/en.22.5.12.s13

23. Sasaki M, North PE, Elsey J, et al. Propranolol exhibits activity against hemangiomas independent of beta blockade. NPJ Precis Oncol. 2019;3:27. doi:10.1038/s41698-019-0099-9

24. Itinteang T, Marsh R, Davis PF, Tan ST. Angiotensin II causes cellular proliferation in infantile haemangioma via angiotensin II receptor 2 activation. $J$ Clin Pathol. 2015;68(5):346-350. doi:10.1136/jclinpath-2014-202794
25. Itinteang T, Brasch HD, Tan ST, Day DJ. Expression of components of the renin-angiotensin system in proliferating infantile haemangioma may account for the propranolol-induced accelerated involution. J Plast Reconstr Aesthet Surg. 2011;64(6):759-765. doi:10.1016/j.bjps.2010.08.039

26. van Schaijik B, Tan ST, Marsh RW, Itinteang T. Expression of (pro) renin receptor and its effect on endothelial cell proliferation in infantile hemangioma. Pediatr Res. 2019;86(2):202-207. doi:10.1038/ s41390-019-0430-8

27. Sulzberger L, Baillie R, Itinteang T, et al. Serum levels of renin, angiotensin-converting enzyme and angiotensin II in patients treated by surgical excision, propranolol and captopril for problematic proliferating infantile haemangioma. J Plast Reconstr Aesthet Surg. 2016;69(3):381-386. doi:10.1016/j.bjps.2015.10.020

28. Balakumar P, Jagadeesh G. Potential cross-talk between (pro)renin receptors and Wnt/frizzled receptors in cardiovascular and renal disorders. Hypertens Res. 2011;34(11):1161-1170. doi:10.1038/ hr.2011.113

29. Moisan F, Oucherif S, Kaulanjan-Checkmodine P, et al. Critical role of Aquaporin-1 and telocytes in infantile hemangioma response to propranolol beta blockade. Proc Natl Acad Sci U S A. 2021;118:7. doi:10.1073/pnas.2018690118

30. Chim H, Armijo BS, Miller E, Gliniak C, Serret MA, Gosain AK. Propranolol induces regression of hemangioma cells through HIF-1alpha-mediated inhibition of VEGF-A. Ann Surg. 2012;256 (1):146-156. doi:10.1097/SLA.0b013e318254ce7a

31. Tani S, Kunimoto K, Inaba Y, et al. Change of serum cytokine profiles by propranolol treatment in patients with infantile hemangioma. Drug Discov Ther. 2020;14(2):89-92. doi:10.5582/ ddt.2020.03014

32. Pandey A, Singh A, Ali W, et al. Evaluation of effect of propranolol on serum vascular endothelial growth factor and tissue inhibitor of metalloproteinase-2 levels in infantile hemangioma. J Indian Assoc Pediatr Surg. 2020;25(2):96-102. doi:10.4103/jiaps.JIAPS_22_19

33. Takechi T, Kumokawa T, Kato R, Higuchi T, Kaneko T, Ieiri I. Population pharmacokinetics and pharmacodynamics of oral propranolol in pediatric patients with infantile hemangioma. $J$ Clin Pharmacol. 2018;58(10):1361-1370. doi:10.1002/jcph.1149

34. Vignaduzzo SE, Maggio RM, Castellano PM, Kaufman TS. PLS and first derivative of ratio spectra methods for determination of hydrochlorothiazide and propranolol hydrochloride in tablets. Anal Bioanal Chem. 2006;386(7-8):2239-2244. doi:10.1007/s00216-006-0861-z

35. Leaute-Labreze C, Hoeger P, Mazereeuw-Hautier J, et al. A randomized, controlled trial of oral propranolol in infantile hemangioma. $N$ Engl J Med. 2015;372(8):735-746. doi:10.1056/ NEJMoa1404710

36. Itinteang T, Tan ST, Guthrie S, et al. A placental chorionic villous mesenchymal core cellular origin for infantile haemangioma. J Clin Pathol. 2011;64(10):870-874. doi:10.1136/jclinpath-2011-200191

37. de Jong S, Itinteang T, Withers AH, Davis PF, Tan ST. Does hypoxia play a role in infantile hemangioma? Arch Dermatol Res. 2016;308 (4):219-227. doi:10.1007/s00403-016-1635-x

38. Storch $\mathrm{CH}$, Hoeger PH. Propranolol for infantile haemangiomas: insights into the molecular mechanisms of action. $\mathrm{Br} J$ Dermatol. 2010;163(2):269-274. doi:10.1111/j.1365-2133.2010.09848.x

39. Sommers Smith SK, Smith DM. Beta blockade induces apoptosis in cultured capillary endothelial cells. In Vitro Cell Dev Biol Anim. 2002;38(5):298-304. doi:10.1290/1071-2690(2002)038<0298: BBIAIC $>2.0 . \mathrm{CO} ; 2$

40. Overman J, Fontaine F, Wylie-Sears J, et al. R-propranolol is a small molecule inhibitor of the SOX18 transcription factor in a rare vascular syndrome and hemangioma. Elife. 2019;8:e43026. doi:10.7554/ eLife. 43026

41. Wolter JK, Wolter NE, Blanch A, et al. Anti-tumor activity of the beta-adrenergic receptor antagonist propranolol in neuroblastoma. Oncotarget. 2014;5(1):161-172. doi:10.18632/oncotarget.1083 
42. Chang PY, Huang WY, Lin CL, et al. Propranolol reduces cancer risk: a population-based cohort study. Medicine. 2015;94(27):e1097. doi:10.1097/MD.0000000000001097

43. Villani R, Hodgson S, Legrand J, et al. Dominant-negative Sox 18 function inhibits dermal papilla maturation and differentiation in all murine hair types. Development. 2017;144(10):1887-1895. doi: $10.1242 /$ dev. 143917

44. Francois M, Caprini A, Hosking B, et al. Sox18 induces development of the lymphatic vasculature in mice. Nature. 2008;456 (7222):643-647. doi:10.1038/nature07391

45. Price CJ, Lattouf C, Baum B, et al. Propranolol vs corticosteroids for infantile hemangiomas: a multicenter retrospective analysis. Arch Dermatol. 2011;147(12):1371-1376. doi:10.1001/ archdermatol.2011.203

46. Kardasevic M, Dinarevic SM. Infantile sacral region hemangioma and combination treatment with propranolol and topical timolol: case review and reference review. Med Arch. 2021;75(2):158-161. doi:10.5455/medarh.2021.75.158-161

47. Kridin K, Pam N, Bergman R, Khamaysi Z. Oral propranolol administration is effective for infantile hemangioma in late infancy: a retrospective cohort study. Dermatol Ther. 2020;33(3):e13331. doi: $10.1111 /$ dth. 13331

48. Costa MC, Andrade OGC, Pereira LC, Costa IMC. Success in the use of oral propranolol in the treatment of infantile hemangioma in nasal tip - Report of two cases. An Bras Dermatol. 2020;95(2):207-209. doi:10.1016/j.abd.2019.05.005

49. Saerens J, Gutermuth J, Janmohamed SR. An infant with localized vasoconstriction following topical propranolol exposure for infantile hemangioma. Pediatr Dermatol. 2021;38(1):263-264. doi:10.1111/ pde. 14475

50. Kreshanti P, Putri NT, Martin VJ, Sukasah CL. The effectiveness of oral propranolol for infantile hemangioma on the head and neck region: a case series. Int J Surg Case Rep. 2021;84:106120. doi:10.1016/j.ijscr.2021.106120

51. Ishikawa K, Fujita $M$, Takeda $T$, et al. Ulcerated infantile hemangioma of the hard palate: diagnostic treatment with oral propranolol. $J \quad$ Craniofac Surg. 2020;31(6):e600-e602. doi:10.1097/ SCS.0000000000006666

52. Chung SH, Park DH, Jung HL, et al. Successful and safe treatment of hemangioma with oral propranolol in a single institution. Korean J Pediatr. 2012;55(5):164-170. doi:10.3345/kjp.2012.55.5.164

53. Blatt J, Morrell DS, Buck S, et al. $\beta$-blockers for infantile hemangiomas: a single-institution experience. Clin Pediatr. 2011;50 (8):757-763. doi:10.1177/0009922811405517

54. Giese RA, Turner M, Cleves M, Gardner JR, Richter GT. Propranolol for treatment of infantile hemangioma: efficacy and effect on pediatric growth and development. Int J Pediatr. 2021;2021:6669383. doi:10.1155/2021/6669383

55. Park M, Jung HL, Shim YJ, et al. Serum cytokine profiles in infants with infantile hemangiomas on oral propranolol treatment: VEGF and bFGF, potential biomarkers predicting clinical outcomes. Pediatr Res. 2020;88(5):749-755. doi:10.1038/s41390-020-0862-1

56. Yun YJ, Gyon YH, Yang S, Lee YK, Park J, Park M. A prospective study to assess the efficacy and safety of oral propranolol as first-line treatment for infantile superficial hemangioma. Korean $J$ Pediatr. 2015;58(12):484-490. doi:10.3345/kjp.2015.58.12.484

57. Smithson SL, Rademaker M, Adams S, et al. Consensus statement for the treatment of infantile haemangiomas with propranolol. Australas J Dermatol. 2017;58(2):155-159. doi:10.1111/ajd.12600

58. Leaute-Labreze C, Boccara O, Degrugillier-Chopinet C, et al. Safety of oral propranolol for the treatment of infantile hemangioma: a systematic review. Pediatrics. 2016;138(4):e20160353. doi:10.1542/peds.2016-0353

59. Tollefson MM, Frieden IJ. Early growth of infantile hemangiomas: what parents' photographs tell us. Pediatrics. 2012;130(2):e314e320. doi:10.1542/peds.2011-3683
60. Chakkittakandiyil A, Phillips R, Frieden IJ, et al. Timolol maleate $0.5 \%$ or $0.1 \%$ gel-forming solution for infantile hemangiomas: a retrospective, multicenter, cohort study. Pediatr Dermatol. 2012;29(1):28-31. doi:10.1111/j.1525-1470.2011.01664.x

61. Kollipara R, Odhav A, Rentas KE, Rivard DC, Lowe LH, Dinneen L. Vascular anomalies in pediatric patients: updated classification, imaging, and therapy. Radiol Clin North Am. 2013;51(4):659-672. doi:10.1016/j.rcl.2013.04.002

62. Johnson EF, Davis DM, Tollefson MM, Fritchie K, Gibson LE. Vascular tumors in infants: case report and review of clinical, histopathologic, and immunohistochemical characteristics of infantile hemangioma, pyogenic granuloma, noninvoluting congenital hemangioma, tufted angioma, and kaposiform hemangioendothelioma. Am J Dermatopathol. 2018;40 (4):231-239. doi:10.1097/DAD.0000000000000983

63. George A, Mani V, Noufal A. Update on the classification of hemangioma. J Oral Maxillofac Pathol. 2014;18(Suppl 1):S117S120. doi:10.4103/0973-029X.141321

64. Mimura H, Akita S, Fujino A, et al. Japanese clinical practice guidelines for vascular anomalies 2017. Jpn J Radiol. 2020;38(4):287-342.

65. Goto K, Ozeki M, Yasue S, Endo S, Fukao T. A retrospective study of 2 or $3 \mathrm{mg} / \mathrm{kg} /$ day propranolol for infantile hemangioma. Pediatr Int. 2020;62(6):751-753. doi:10.1111/ped.14181

66. Baselga Torres E, Bernabeu Wittel J, van Esso Arbolave DL, et al. [Spanish consensus on infantile haemangioma]. An Pediatr. 2016;85 (5):256-265. Spanish. doi:10.1016/j.anpedi.2015.10.004

67. Itinteang T, Tan ST, Brasch HD, Vishvanath A, Day DJ. Primitive erythropoiesis in infantile haemangioma. Br J Dermatol. 2011;164 (5):1097-1100. doi:10.1111/j.1365-2133.2010.10187.x

68. Johansen ML, Mahendran G, Lawley LP. Is prolonged monitoring necessary? An updated approach to infantile hemangioma treatment with oral propranolol. Pediatr Dermatol. 2021;38(4):800-805. doi:10.1111/pde.14651

69. Tan CE, Itinteang T, Leadbitter P, Marsh R, Tan ST. Low-dose propranolol regimen for infantile haemangioma. $J$ Paediatr Child Health. 2015;51(4):419-424. doi:10.1111/jpc.12720

70. Drolet BA, Frommelt PC, Chamlin SL, et al. Initiation and use of propranolol for infantile hemangioma: report of a consensus conference. Pediatrics. 2013;131(1):128-140. doi:10.1542/peds.2012-1691

71. El Ezzi O, Hohlfeld J, de Buys Roessingh A. Propranolol in infantile haemangioma: simplifying pretreatment monitoring. Swiss Med Wkly. 2014;144:w13943.

72. Chamlin SL, Haggstrom AN, Drolet BA, et al. Multicenter prospective study of ulcerated hemangiomas. $J$ Pediatr. 2007;151 (6):684-689. doi:10.1016/j.jpeds.2007.04.055

73. Shin HT, Orlow SJ, Chang MW. Ulcerated haemangioma of infancy: a retrospective review of 47 patients. $B r J$ Dermatol. 2007;156 (5):1050-1052. doi:10.1111/j.1365-2133.2007.07771.x

74. Ovadia SA, Landy DC, Cohen ER, Yang EY, Thaller SR. Local administration of beta-blockers for infantile hemangiomas: a systematic review and meta-analysis. Ann Plast Surg. 2015;74 (2):256-262. doi:10.1097/SAP.0000000000000390

75. Marqueling AL, Oza V, Frieden IJ, Puttgen KB. Propranolol and infantile hemangiomas four years later: a systematic review. Pediatr Dermatol. 2013;30(2):182-191. doi:10.1111/pde.12089

76. Hermans DJ, Bauland CG, Zweegers J, van Beynum IM, van der Vleuten CJ. Propranolol in a case series of 174 patients with complicated infantile haemangioma: indications, safety and future directions. Br J Dermatol. 2013;168(4):837-843. doi:10.1111/ bjd.12189

77. Hogeling M, Adams S, Wargon O. A randomized controlled trial of propranolol for infantile hemangiomas. Pediatrics. 2011;128(2): e259-e266. doi:10.1542/peds.2010-0029

78. Phillips RJ, Penington AJ, Bekhor PS, Crock CM. Use of propranolol for treatment of infantile haemangiomas in an outpatient setting. $J$ Paediatr Child Health. 2012;48(10):902-906. doi:10.1111/j.14401754.2012.02521.x 
79. Shah SD, Baselga E, McCuaig C, et al. Rebound growth of infantile hemangiomas after propranolol therapy. Pediatrics. 2016;137(4) e20151754. doi:10.1542/peds.2015-1754

80. Pam N, Kridin K, Khamaysi Z. Propranolol for infantile hemangioma: evaluating efficacy and predictors of response and rebound growth. Dermatol Ther. 2021;34(3):e14936. doi:10.1111/dth.14936

81. Horbach SER, van der Horst C, Blei F, et al. Development of an international core outcome set for peripheral vascular malformations: the OVAMA project. $\mathrm{Br} J$ Dermatol. 2018;178(2):473-481. doi:10.1111/bjd.16029

82. Lee JC, Modiri O, England RW, Shawber CJ, Wu JK. Propranolol therapy in infantile hemangioma: it is not just about the beta. Plast Reconstr Surg 2021;147(4):875-885. doi:10.1097/PRS.0000000000007699

83. Theiler M, Knopfel N, von der Heydt S, et al. Sleep behavior of infants with infantile hemangioma treated with propranolol-a cohort study. Eur J Pediatr. 2021;180(8):2655-2668. doi:10.1007/s00431021-04147-3

84. Pandey V, Tiwari P, Imran M, Mishra A, Kumar D, Sharma SP. Adverse drug reactions following propranolol in infantile hemangioma. Indian Pediatr. 2021;58(8):753-755. doi:10.1007/ s13312-021-2286-3

85. Xerfan EMS, Andersen ML, Facina AS, Tufik S, Tomimori J. Sleep disturbances as an adverse effect of propranolol use in children with infantile hemangioma. World J Pediatr. 2020;16(5):537-538. doi:10.1007/s12519-019-00335-2

86. Ji Y, Chen S, Yang K, et al. Efficacy and safety of propranolol vs atenolol in infants with problematic infantile hemangiomas: a randomized clinical trial. JAMA Otolaryngol Head Neck Surg. 2021;147(7):599-607. doi:10.1001/jamaoto.2021.0454
87. Ji Y, Chen S, Wang Q, et al. Intolerable side effects during propranolol therapy for infantile hemangioma: frequency, risk factors and management. Sci Rep. 2018;8(1):4264. doi:10.1038/s41598-01822787-8

88. Yang H, Hu DL, Shu Q, Guo XD. Efficacy and adverse effects of oral propranolol in infantile hemangioma: a meta-analysis of comparative studies. World J Pediatr. 2019;15(6):546-558. doi:10.1007/s12519019-00285-9

89. Chang L, Ye X, Qiu Y, et al. Is propranolol safe and effective for outpatient use for infantile hemangioma? A prospective study of 679 cases from one center in China. Ann Plast Surg. 2016;76(5):559-563. doi:10.1097/SAP.0000000000000506

90. Thai T, Wang CY, Chang CY, Brown JD. Central nervous system effects of oral propranolol for infantile hemangioma: a systematic review and meta-analysis. J Clin Med. 2019;8(2):268. doi:10.3390/ jcm8020268

91. Moyakine AV, Kerstjens JM, Spillekom-van Koulil S, van der Vleuten CJ. Propranolol treatment of infantile hemangioma (IH) is not associated with developmental risk or growth impairment at age 4 years. J Am Acad Dermatol. 2016;75(1):59-63 e51. doi:10.1016/j. jaad.2016.02.1218

92. Langley A, Pope E. Propranolol and central nervous system function: potential implications for paediatric patients with infantile haemangiomas. $B r J$ Dermatol. 2015;172(1):13-23. doi:10.1111/ bjd. 13379

\section{Publish your work in this journal}

Clinical, Cosmetic and Investigational Dermatology is an international, peer-reviewed, open access, online journal that focuses on the latest clinical and experimental research in all aspects of skin disease and cosmetic interventions. This journal is indexed on CAS.
The manuscript management system is completely online and includes a very quick and fair peer-review system, which is all easy to use. Visit http://www.dovepress.com/testimonials.php to read real quotes from published authors. 